Original Article

\title{
THE PROTECTIVE EFFECTS OF ARGANIA SPINOSA SEEDS AGAINST HYPER- HOMOCYSTENEMIA INDUCED BY HIGH METHIONINE DIET IN MICE
}

\author{
BADIAA AKLIL ${ }^{1,2}$, SAKINA ZERIZER ${ }^{* 1,2}$, ZAHIA KABOUCHE ${ }^{1}$ \\ 1.2Université Des Frères Mentouri-Constantine, Département de Biologie Animale, Laboratoire d’Obtention de Substances Thérapeutiques \\ (L. O. S. T), 25000 Constantine, Algeria
}

Email: zerizer.sakina@umc.edu.dz

Received: 10 Mar 2017 Revised and Accepted: 16 Oct 2017

\begin{abstract}
Objective: Hyperhomocysteinemia (HHCY), oxidative stress and decreased antioxidant capacities lead to several clinical manifestations and particularly, cardiovascular and liver diseases. Our aim in this study was to investigate the protective effects of Argania spinosa powdered seeds
\end{abstract} against high methionine diet-induced HHCY, oxidative stress and damages in the aorta, and heart of mice.

Methods: Adult male Mus Musculus was systematically divided into four groups of similar mean body weights and fed for $21 \mathrm{~d}$ with control and experimental diets. The control group (F) was fed with white bread (0.50 mg/mice), group (M) was fed with L-methionine (500 mg/kg/day), group (MP) was fed with L-methionine (500 mg/kg/day) plus A. spinosa powdered seeds $150 \mathrm{mg} / \mathrm{kg}$ ), and the group (P) was treated with A. spinosa powdered seeds $(150 \mathrm{mg} / \mathrm{kg} /$ day $)$. The experimental diets were given in white bread $(0.50 \mathrm{mg} / \mathrm{mice})$. After 3 weeks of treatments, homocysteine (HCY) concentrations, hepatic antioxidant status and histological sections of aorta and heart were determined.

Results: Consumption of high methionine diet led to an increase in plasma HCY, reduced the concentrations of GSH, and the enzyme catalase. These were associated with the loss and degeneration of endothelium, fenestration and formation of foam cells of the aorta, also the alteration of the cardiac muscle. However, administration of $A$. spinosa powdered seeds in combination with methionine decreased the concentration of HCY from $(10.04 \pm 0.83 \mu \mathrm{mol} / \mathrm{l})$ to $(7.26 \pm 0.46 \mu \mathrm{mol} / \mathrm{l})$, increased catalase activity from $(45.82 \pm 5.83 \mathrm{~m} \mathrm{~mol} / \mathrm{mg}$ protein) to $(62.26 \pm 3.32 \mathrm{~m} \mathrm{~mol} / \mathrm{mg}$ protein), and ameliorated histological changes.

Conclusion: A. spinosa powdered seeds were effectives in decreasing plasma HCY level as induced by methionine-enriched diet in mice, and improved the antioxidants defence.

Keywords: Homocysteine, Argania spinosa, Antioxidant enzymes, Methionine, Oxidative stress, Cardiovascular diseases

(C) 2017 The Authors. Published by Innovare Academic Sciences Pvt Ltd. This is an open-access article under the CC BY license (http://creativecommons.org/licenses/by/4.0/) DOI: http://dx.doi.org/10.22159/ijpps.2017v9i12.18275

\section{INTRODUCTION}

Both cardiovascular disease and liver injury are major public health issues [1]. It has been reported that elevated plasma HCY concentration is an important risk factor for vascular diseases [2-3], and defects in methyl group metabolism, often resulting in HHCY, are among the key molecular events postulated to play a role in liver injury [1]. Plasma HCY levels can be determined by genetic, biological, nutritional, hormonal and lifestyle factors [4].

HHCY caused by excessive methionine intake is a classical attribute cardiovascular [5] and hepatic diseases [6-7]. Due to the presence of the highly reactive sulfhydryl group, HCY can undergo autooxidation to generate oxygen radicals [8].

Studies have shown that high HCY concentration could cause oxidative damage to cells [9-10]. HHCY induces endothelial dysfunction [11], which played an important role in the early stages of the atherogenic process by decreasing the availability of NO, stimulating the activation of nuclear factor kappa B and consequently increasing the expression of ICAM-1 [12]. Indeed, the oxidative stress resulting from elevated serum Hcy can oxidize membrane lipids and proteins and stimulate the activation of NF-B, and consequently increase the expression of inflammatory factors in vivo [13].

Hyperhomocysteinemia leads to increased oxidative stress via the generation of reactive oxygen species which weaken intracellular antioxidation defence systems [14]. ROS (including superoxide and hydrogen peroxide) are produced by endothelial cells and the adjacent smooth muscle cells, adventitial fibroblasts and inflammatory cells. ROS can affect the NO pathway [15]. The need for protection against ROS and other reactive molecules has led to the specious theory that a high intake of exogenous antioxidants protects the body from oxidative stress, which is also widely known as the antioxidant hypothesis [16-17].

A high intake of fruit and vegetables rich in natural antioxidants, such as vitamins $\mathrm{C}$ and $\mathrm{E}$, polyphenols, carotenoids, terpenoids, and phytomicronutrients, show an inverse association with the risk of cancer and the development of cardiovascular diseases.

The argan tree (Argania spinosa (L.) Skeels is a tropical plant, which belongs to the Sapotaceae family and is endemic in southwestern Morocco [19], and Algerian region of Tindouf [20]. It is exploited essentially for its fruits. The endosperm seed of fruit constitutes a good potential source of edible oil for human consumption and endowed with important medicinal properties [19].

Considering its rich composition in antioxidant compounds and unsaturated fat, $A$. spinosa can be used as a nutritional intervention in the CVD diseases prevention [21]

This study was designed to investigate the beneficial effects of powdered seeds of A. spinosa against hyper-homocystenemia, antioxidant status and damages in the heart and aorta induced by high methionine intake in mice.

\section{MATERIALS AND METHODS}

\section{Plant material}

Seeds of Argania spinosa were collected from a region near Tindouf (Southwest of Algeria). The fruits were cut into pieces to obtain seeds, which were subjected to size reduction to a coarse powder using a mechanical grinder. The powder was then used for treatment preparations. 


\section{Chemicals and reagents}

L-Methionine purity $98 \%$ was obtained from across organics (Belgium). Total HCY levels were measured using the Immulite HCY kit (Siemens, Finland), on Immulite 2000 system. Other chemicals used were of Sigma chemical company.

\section{Animals}

Experiments were performed on 28 adult male Albino Mus Musculus mice weighing (30-35g), given from central pharmacy, Algeria. Animals were housed 7 per cage, and maintained under standard laboratory conditions of humidity, temperature $\left(25^{\circ} \mathrm{C}\right)$ and light $(12 \mathrm{~h}$ day: $12 \mathrm{~h}$ night). After the adaptive period, they were divided into four groups of similar mean body weights and fed for $21 \mathrm{~d}$ with control and experimental diets. The control group (F) was fed with white bread $(0.50$ $\mathrm{mg} /$ mice), the second group (M) was fed with L-methionine (500 $\mathrm{mg} / \mathrm{kg} /$ day), the third group (MP) was fed with L-methionine (500 $\mathrm{mg} / \mathrm{kg} /$ day) in combination with powdered seeds of $A$. spinosa (150 $\mathrm{mg} / \mathrm{kg} /$ day), while the group (P) was treated with powdered seeds of $A$. spinosa $(150 \mathrm{mg} / \mathrm{kg} /$ day). The experimental diets were given in white bread $(0.50 \mathrm{mg} / \mathrm{mice})$ and allowed free access to food and water. After 3 $\mathrm{w}^{*}$ of feeding, blood samples were collected after fasting, from the retro orbital plexus into EDTA tubes by using glass capillaries. They were centrifuged immediately, and plasma was frozen under- $20{ }^{\circ} \mathrm{C}$ until assay time. The experiments were conducted in strict compliance according to ethical principles and provided by the committee for the purpose of control and supervision of Experiments on the animal (CPCSEA).

\section{Determination of homocysteine level}

The levels of total homocysteine ( $\mathrm{t}-\mathrm{HCY}$ ) were assayed by competitive solid phase chemiluminescence immunoassay.

\section{Tissue homogenate preparation}

$0.5 \mathrm{~g}$ of the liver was homogenized in $2 \mathrm{ml}$ of TBS (Tris $50 \mathrm{mmol}$, $\mathrm{NaCl} 150 \mathrm{mmol}, \mathrm{pH}$ 7.4). The homogenates were centrifuged at 9000 $\mathrm{g}$ for $15 \mathrm{~min} \mathrm{at}^{\circ} \mathrm{C}$, and the resultant supernatant was used for determination of: reduced glutathione, the catalase activities and protein concentrations.

\section{Protein quantification}

Protein was measured by the method of Bradford (1976) [22], using bovine serum albumin as the standard.

\section{Determination of reduced glutathione (GSH)}

The glutathione reduced content in the liver was measured spectrophotometrically by using 5,5 -dithiobis- $(2$ nitrobenzoic acids) (DTNB) as a coloring reagent, following the method described by Weeckbeker and cory (1988) [23].

\section{Determination of catalase (CAT)}

Tissue CAT activity was determined according to Aebi's method (1974) [24]. The principle of the assay based on the determination $\mathrm{H} 2 \mathrm{O} 2$ decomposition rate at $240 \mathrm{~nm}$.

\section{Histological sections}

After the blood samples collection, the animals were sacrificed and organs designed for morphological analysis (heart, and aortas) were quickly removed, rinsed with saline solution $(0.9 \%)$, and fixed in formalin $10 \%$. The processed tissues were embedded in paraffin, sectioned at $5 \mu \mathrm{m}$ thickness, and stained following the haematoxylin eosin staining method.

\section{Statistical analysis}

The values obtained were expressed as mean \pm SEM and subjected to statistical analysis using one-way analysis of variance (ANOVA), followed by Tukey's post-hoc test (SPSS version 20). $P<0.05$ values were considered as significantly difference.

\section{RESULTS}

\section{Effects of treatments on HCY}

At the third week, plasma HCY of the (M) group achieved higher levels, and the average was $10.04 \pm 0.83 \mu \mathrm{mol} / \mathrm{l}$, significantly higher than that of the control group (F) $(6,84 \pm 0.51 \mu \mathrm{mol} / \mathrm{l})$ and control positive group (P) $(7.1 \pm 0.88 \mu \mathrm{mol} / \mathrm{l})$. However, the combined treatments of $A$. spinosa powdered seeds with methionine $(7.26 \pm 0.46 \mu \mathrm{mol} / \mathrm{l})$ showed a significant decline in serum t-HCY, demonstrating that $A$. spinosa appears to be effective in preventing the increase of t-HCY levels (fig. 1).

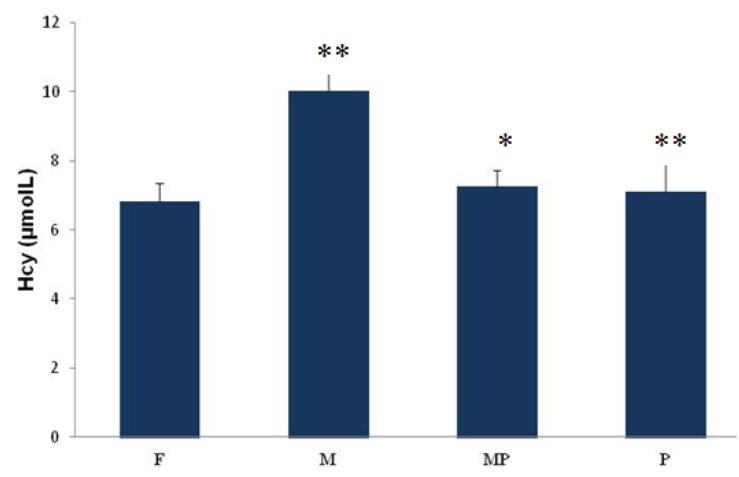

Fig. 1: The interaction of L-methionine and $A$. spinosa seeds on the plasma homocysteine in mice during $21 \mathrm{~d}$ of treatment, Values are the means \pm SEM (n); ${ }^{*} \mathbf{p}<0.05$ and ${ }^{* *}$ p $<0.01$

\section{Effects of treatments on hepatic anti-oxidative stress parameter}

The present data showed that there is a highly significant depletion in reduced glutathione level $(4.48 \pm 0.55 \mathrm{n} \mathrm{mol} / \mathrm{mg}$ protein $)(\mathrm{P}<0.01)$ and a significant decrease in catalase activity $(45.82 \pm 5.83 \mathrm{~m} \mathrm{~mol} / \mathrm{mg}$ protein) $(\mathrm{P}<0.05)$, for the group $(\mathrm{M})$ in comparison with control group (F), where the reduced GSH level was $(8.03 \pm 0.55 \mathrm{n} \mathrm{mol} / \mathrm{mg}$ protein) and the concentration of catalase was $(61.37 \pm 6.39 \mathrm{~m}$ $\mathrm{mol} / \mathrm{mg}$ protein). However the concentration of reduced GSH increased significantly in the group (P) $(7.36 \pm 1.28 \mathrm{n} \mathrm{mol} / \mathrm{mg}$ protein) $(\mathrm{P}<0.01)$, and not significantly with the group $(\mathrm{MP})(6.1 \pm 0.5$ $\mathrm{n} \mathrm{mol} / \mathrm{mg}$ protein) $(\mathrm{P}>0.05)$. On the other hand, the concentration of catalase increased significantly in the group (MP) $(62.26 \pm 3.32 \mathrm{~m}$ $\mathrm{mol} / \mathrm{mg}$ protein $)(\mathrm{P}<0.05)$, but not significantly in the group $(\mathrm{P})$ (52.16 $\pm 3.19 \mathrm{~m} \mathrm{~mol} / \mathrm{mg}$ protein) ( $\mathrm{P}>0.05$ ) (fig. 2).

Histological impact of $A$. spinosa powdered seeds on heart and aortas tissues

Our data shows various pathological alterations in the heart and aorta of mice induced by the oral methionine administration.

In the second group (M) which had been fed with $500 \mathrm{mg} / \mathrm{kg}$ of methionine, Microscopic observation of heart was characterized by the presence of lysis, and architectural changes of cardiomyocytes as shown in (fig. 3-B and 3-C). In the other groups: (F), (MP) and (P), we have not observed any alteration in contrast to methionine intake group (fig. 3-A, 3-D and 3-E).

In the group (M), the aortic intima showed degeneration and desquamation of endothelial cells with fenestration, we also observed in the media lysis, formation of foam cells laden with small lipid droplets and oval nuclei as illustrated in (fig. 4-B and 4-C), (fig. 5-B) and (fig. 6-B, 6-C, 6-D and 6-E).

However, in the control group (F), the aortic sections have intact endothelium and spindle-shaped meiocytes nuclei as shown in (fig. 4-A, 5-A and 6-A). Also, we have observed intact aorta in the group (MP) treated with L-methionine and A. spinosa (fig. 4-D, 5-C and 6F), and in the group (P) treated with A. spinosa only (fig. 4-E, 5-D and 6-G).

\section{DISCUSSION}

Hyper-homocystenemia can arise from nutritional deficiencies of folate, vitamin B6, and vitamin B12 [25]. Several diseases such as renal and thyroid dysfunction cancer, psoriasis, and diabetes as well as various drugs, alcohol, tobacco, coffee, older age and menopause, are believed to be associated with moderately elevated HCY concentrations [26]. There has been an indication towards a 
significant correlation between HHCY and cardiovascular disease and its complications such as heart attacks and strokes [27]. It is believed that hyperhomocysteinemia leads to endothelial cell damage, reduction in the flexibility of vessels, and alters the process of homeostasis [27]. HHCY may lead to an enhancement of the adverse effects of risk factors like hypertension, smoking, lipid and lipoprotein metabolism, as well as the promotion of the development of inflammation. Physical activity, moderate alcohol consumption, good folate and vitamin B12 status are associated with lower HCY levels.
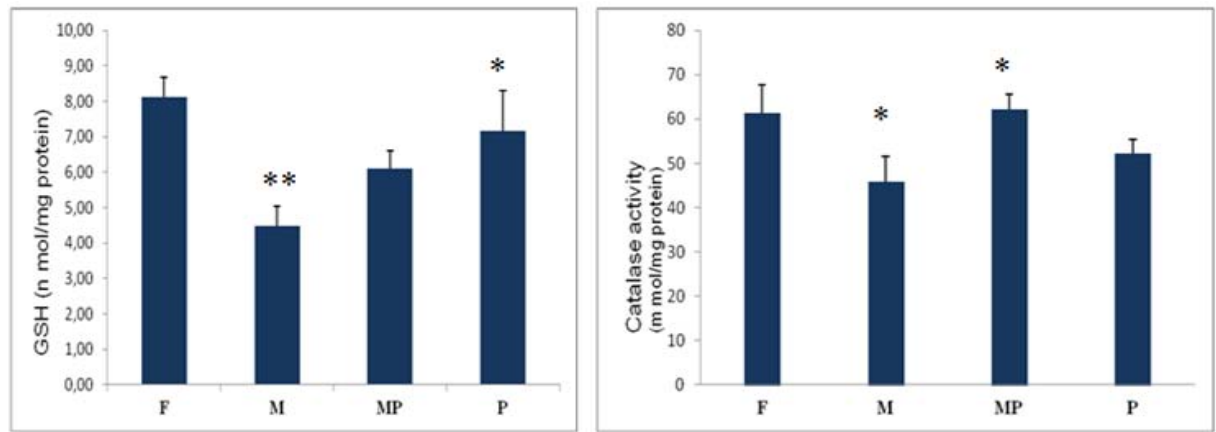

Fig. 2: The interaction of L-methionine and $A$. spinosa seeds on the reduced glutathione levels, and catalase activity in mice during $21 \mathrm{~d}$ of treatment, values are the means \pm SEM (n); ${ }^{*} p<0.05$, and ${ }^{* *} p<0.01$
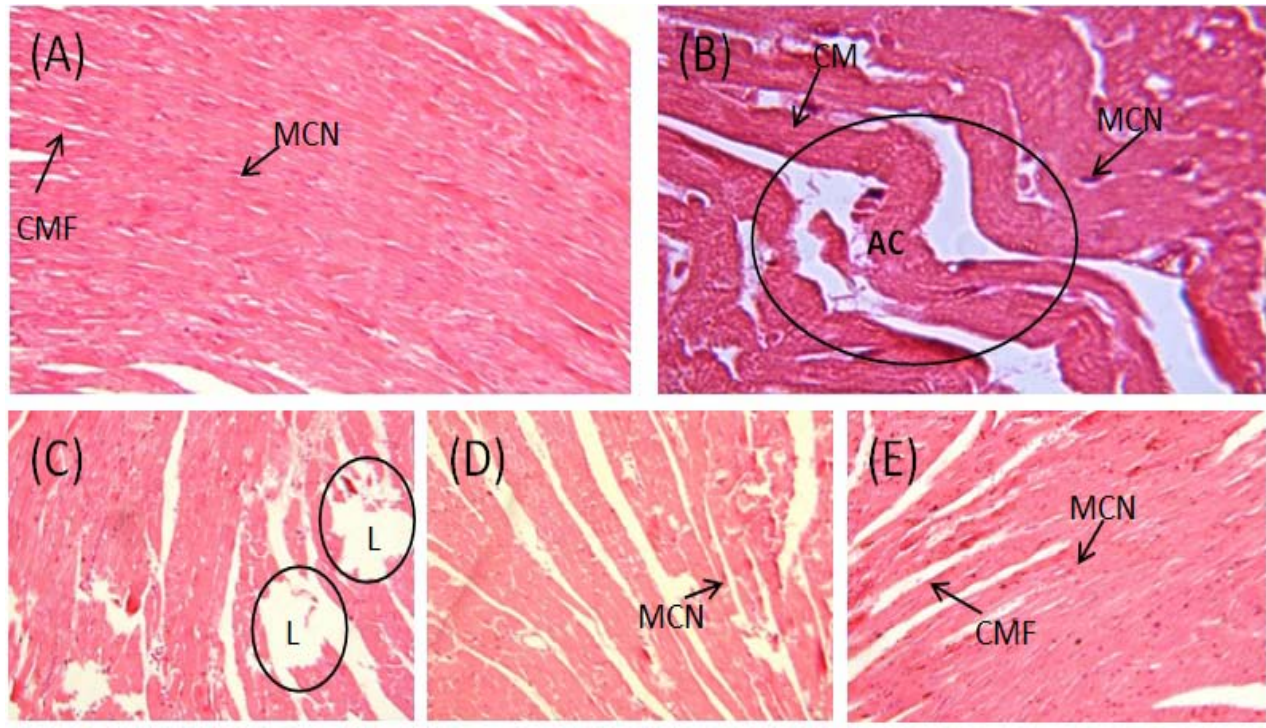

Fig. 3: Histological sections of the heart of (A) control, (B), (C) treated with Methionine, (D), treated with Methionine and A. spinosa powdered seeds and (E) treated with $A$. spinosa powdered seeds for $3 \mathrm{w}^{*}$. Hematoxylin-Eosin Staining (A, C, D and E X100, and B X 400). ACC. Architectural Changes of Cardiomyocytes, CMF. Cardiac Muscle Fibers, MCN. Muscle Cell Nuclei, L. Lysis

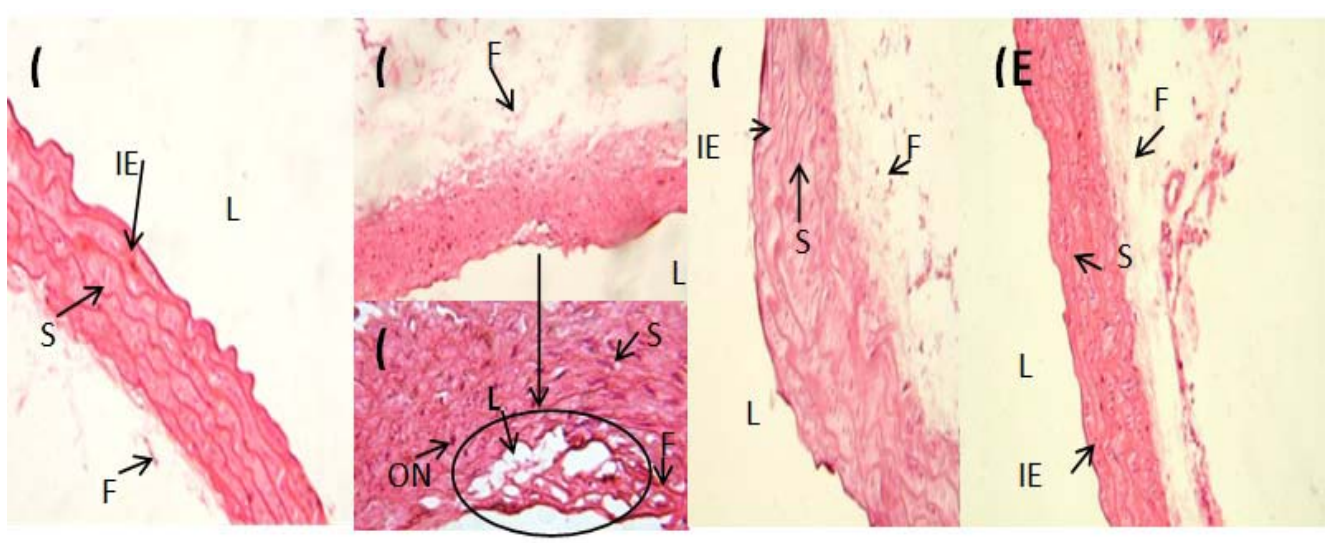

Fig. 4: Histological sections of the arch aorta of (A) control, (B), (C) treated with Methionine, (D), treated with Methionine and A. spinosa powdered seeds and (E) treated with $A$. spinosa powdered seeds for $3 w^{*}$. Hematoxylin-Eosin Staining (A, B, D and E X100, and C X 400).

FC. Foam Cells, FN. Fibroblast Nuclei, IEND. Intact Endothelium, LD. Lipid Droplets, Lu. lumen, ON. Oval Nuclei, SN. Spindle Nuclei 

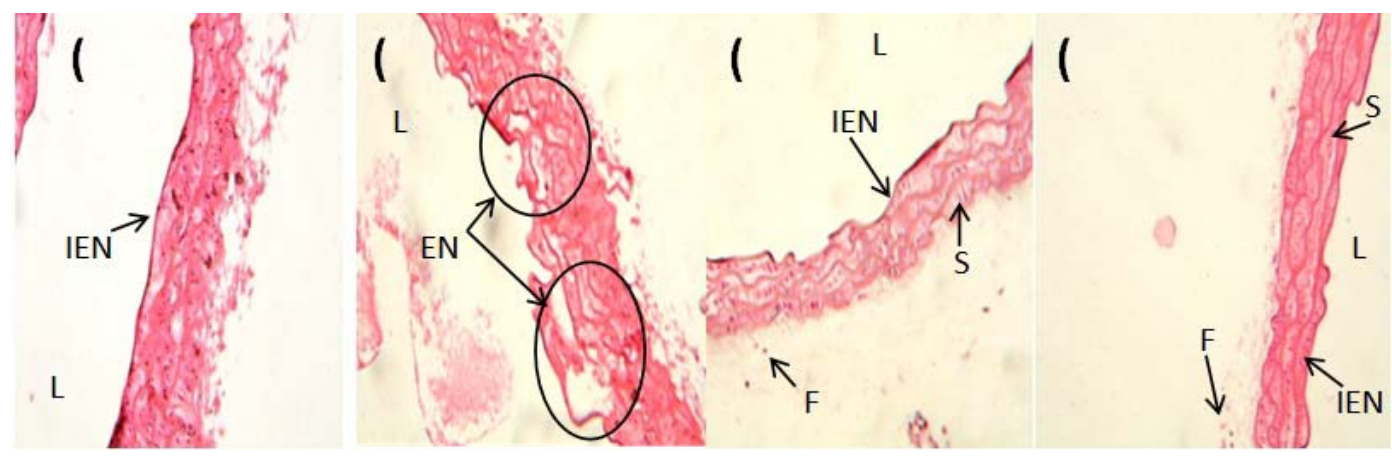

Fig. 5: Histological sections of the abdominal aorta of (A) control, (B) treated with Methionine, (C) treated with Methionine and $A$. spinosa powdered seeds and (D) treated with $A$. spinosa powdered seeds for $3 w^{*}$. Hematoxylin-Eosin Staining (A, B, C and D X100). END. Endolysis, FN. Fibroblast Nuclei, IEND. Intact Endothelium, LU. Lumen, SN. Spindle Nuclei

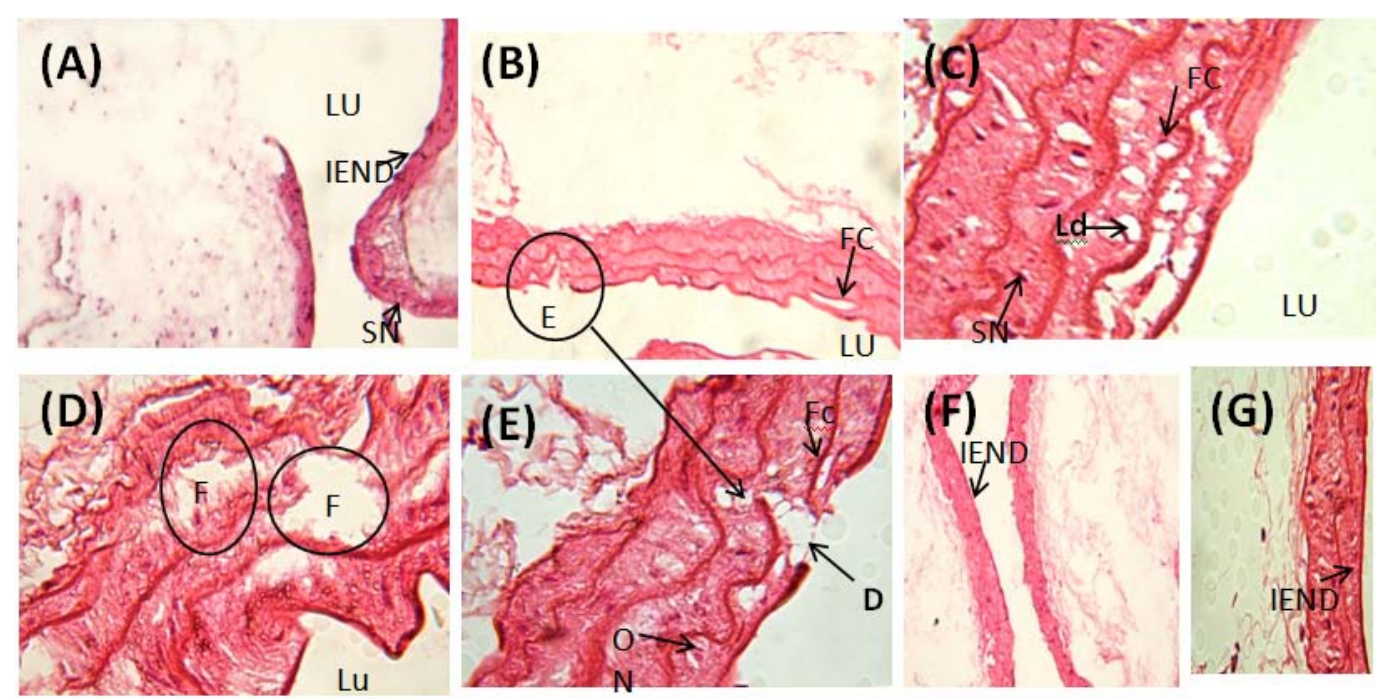

Fig. 6: Histological sections of the iliac aorta of (A) control, (B), (C), (D) and (E) treated with Methionine, (F), treated with Methionine and $A$. spinosa powdered seeds and (G) treated with $A$. spinosa powdered seeds for $3 \mathrm{w}^{*}$. Hematoxylin-Eosin Staining (A, B, D and E X100, and C $X$ 400). D. Desquamation, END. Endolysis, F. Fenestration, FC. Foam Cells, FN. Fibroblast Nuclei, IEND. Intact Endothelium, LU. Lumen, ON. Oval Nuclei, SN. Spindle Nuclei

The current study has shown that high Met-diet in mice during $21 \mathrm{~d}$ clearly caused a significant increase in HCY level and decreased the reduced glutathione, and catalase concentrations in liver, meanwhile our results confirm that high level of HCY might be an effect of aorta and heart damages.

Several studies have shown that methionine enriched-diet induced a significant increase of plasma t-HCY [28-31].

Further, we found that the content of GSH and catalase activities in liver tissue was significantly decreased in response to the oral methionine administration.

hyperaccumulation of methionine sulfoxide in the liver may induce more serious oxidative hepatotoxicity in Cth-/- mice, whose levels of several antioxidative cysteine metabolites, including GSH, and taurine/hypotaurine, were all downregulated [30]. HHCY leads to increased oxidative stress via the generation of reactive oxygen species (ROS) which weaken intracellular antioxidation defence systems or elicit intracellular redox-controlled inflammation responses [32].

Glutathione is a key buffer of intercellular oxidative reduction reaction, and its dependent antioxidant enzymes include glutathione S-transferase (GST) and glutathione peroxidase (GPx), which play a fundamental role in cellular defense against reactive free radical and other oxidant species [33]. In addition, it has been shown that Hcy can directly act on catalase and inhibit the breakdown of $\mathrm{H} 2 \mathrm{O} 2$ by conversion of the enzyme into the inactive form [34]. Loss of catalase activity is associated with increased susceptibility to oxidative stress [35-36]. The mechanism of HCY inhibition of catalase is shared with a number of inhibitors including 3-amino1:2:4:-triazole [37-38] and amyloid-ß [39].

Histological analysis showed that HHCY induced by the high methionine intake prompted an angiotoxic activity on the aorta and cardiac tissue damages. This was observed through the loss and degeneration of endothelium, formation of foam cells in the different sections of the aorta, alteration of the cardiac muscle.

In our experimental situation, is due to elevated HCY levels, which decreases the reduced GSH, and catalase activities, the well-known biomarkers of oxidative stress. Our results are in agreement with $[40,31]$, who reported that HCY-induced injury to the arterial wall is one of the factors that can initiate the process of atherosclerosis, leading to endothelial dysfunction and eventually to heart attacks and strokes [41-42]. Another work of [43] showed that elevated plasma HCY increase cholesterol synthesis, exerts an angiotoxic action direct to the aorta, by the loss of endothelium and degeneration partly with the dissolution of media cells.

Evidence from animal models of HHCY suggests that endothelial dysfunction is largely due to oxidative stress and decreased bioavailability of NO [44], NO may protect against the onset of vascular diseases [45]. 
HCY promoted oxidative stress through the production of reactive oxygen species (ROS). ROS disrupts endothelial cell integrity, which in turn, can cause endothelial cell damage predispose affected vessels to the subsequent development of atherosclerosis [46].

Studies in several animal species, including rabbits, baboons, and rats, have demonstrated desquamation of endothelial cells, fragmentation of the internal elastic lamina, disruption of elastic fibers, and focal areas of smooth muscle hyperplasia [47-48] has been reported that the combination of high methionine and cholesterol increased the alterations of the arterial wall structures and the thickness of the aortic wall in animal models.

In methionine-treated animals, it was shown an aortic angiotoxic action with alterations not observed in the arterial vascular system of other organs. [49] have reported that acute elevations in plasma HCY after methionine loading causes vessel endothelial dysfunction and this could be reversed by administration of vitamin $\mathrm{E}$ in humans.

It has been documented that HCY can interact with different plasma and cellular proteins and by forming mixed disulfide conjugates, alters the physicochemical properties of the affected proteins. This has been also proposed as a potential mechanism for Hcy induced cellular dysfunction [50].

On the other hand, we found that the diet supplemented with the extract crude of $A$. spinosa was effective in prevention against HHCY in mice exposed to a Met-enriched diet by lowering the concentrations of $\mathrm{HCY}$ and increasing the concentrations of glutathione reduced and catalase, indicating that this medicinal plant has the potential to reduce t-HCY levels in vivo.

In addition, other investigators [51-53] reported that catechin, taurine and quercetin supplementation are effective in attenuating the increase of serum HCY level as induced by a Met-enriched diet in rats and mice respectively. The protective effect of argan oil is probably due to its high contents of powerful antioxidants, particularly polyphenols, tocopherols and sterols, which are known as powerful antioxidants [54]. Indeed we demonstrated that powdered seeds of $A$. spinosa when given in combination with high methionine diet increased significantly the catalase activity, but not significantly the GSH level, indicating its benefic effect in prevention against oxidative stress in vivo. In accordance with our results, [20] demonstrated that argan oil treatment increased the GSH against mercuric chloride induced oxidative stress in experimental rats. The elevated level of GSH protects cellular proteins against oxidation through glutathione redox cycle and directly detoxifies reactive species [55]. Our results showed an increase of catalase activities in group (MP) which administered with L-methionine $(500 \mathrm{mg} / \mathrm{kg}$ ) and treated with $A$. spinosa $(150 \mathrm{mg} / \mathrm{kg}$ ), these results are in agreement with those of [56], who showed that the activities of cytosolic CAT were significantly higher in Wistar rats treated with argan oil in comparison with untreated rats.

The work of $[57,40]$ proved that the rats and mice respectively administered with $200 \mathrm{mg} / \mathrm{kg}$ during $21 \mathrm{~d}$ could damage the aorta and heart tissue and the treatment of these animals with vitamins B9, B12 and B6 and Stachys mialhesi extract corrected these alterations. Another work of [58] established that the high level of Hcy could stimulated the angiogenesis on the arota of rats, and the treatment with the extracts of medicinal plants Stachys mialhesi and Chrysanthemum Macrocarpum could inhibited the angiogenesis.

Antioxidants are emerging as prophylactic and therapeutic agents [59]. Furthermore, another study of [60] suggested that an increased intake of antioxidants appeared to be protective in cardiovascular diseases. Epidemiological studies have shown that consumption of food and beverages rich in phenols can reduce the risk of heart disease by slowing the progression of atherosclerosis principally by protecting LDL from oxidation [61].

\section{CONCLUSION}

The current study has shown that the powdered seeds of $A$. spinosa were effective in attenuating the increase of HCY level, improved the antioxidants defence and prevented the endothelial, cardiac alterations, as induced by a Met-enriched diet in mice. It may be interesting in the development of new drugs for cardiovascular diseases induced by hyperhomocysteinemia.

\section{ACKNOWLEDGEMENT}

The authors are grateful to the MESRS (Ministery of Scientific Research, Algeria).

\section{AUTHORS CONTRIBUTION}

BADIAA Aklil carried out the experimental part of the work, performed data analysis and drafted and revised the manuscript. The design of the work and correction of the manuscript was done by the corresponding author Mrs ZERIZER Sakina and ZAHIA Kabouche carried out the phytochemical part. All authors read and approved the final manuscript.

\section{CONFLICT OF INTERESTS}

\section{Declared none}

\section{REFERENCES}

1. Selicharova I, Korinek M, Demianova Z, Chrudinova M Mladkova J, Jiracek J. Effects of hyperhomocysteinemia and betaine-homocysteine S-methyltransferase inhibition on hepatocyte metabolites and the proteome. Biochim Biophysica Acta 2013;1834:1596-606.

2. Agoston-Coldea L, Mocan T, Gatfosse M, Lupu S, Dumitrascu DL. Plasma homocysteine and the severity of heart failure in patients with previous myocardial infarction. Cardiol J 2011;18:55-62.

3. Wang X, Cui L, Joseph J, Jiang B, Pimental D, Handy DE. Homocysteine induces cardiomyocyte dysfunction and apoptosis through p38 MAPK mediated increase in oxidant stress. J Mol Cell Cardiol 2012;52:753-60.

4. Faraci FM, Lentz SR. Hyperhomocysteinemia, oxidative stress, and cerebral vascular dysfunction. Stroke 2004;35:345-7.

5. Clarke R, Daly L, Robinson K. Hyperhomocysteinemia: an independent risk factor for vascular disease. N Engl J Med 1999;324:1149-55.

6. Adinolfi LE, Ingrosso D, Cesaro G, Cimmino A, D'Anto $M$, Capasso R, et al. Hyperhomocysteinemia and the MTHFR C677T polymorphism promote steatosis and fibrosis in chronic hepatitis C patients. Hepatology 2005;41:995-1003.

7. Roblin X, Pofelski J, Zarski JP. Steatosis, chronic hepatitis virus $\mathrm{C}$ infection and homocysteine. Gastroenterol Clin Biol 2007;31:415-20.

8. Glushchenko AV, Jacobsen DW. Molecular targeting of proteins by L-homocysteine: mechanistic implications for vascular disease. Antioxid Redox Signal 2007;9:1883-98.

9. Hogg N. The effect of cysteine on the auto-oxidation of homocysteine. Free Radical Biol Med 1999;27:28-33.

10. Stipanuk MH. Sulfur amino acid metabolism: pathways for production and removal of homocysteine and cysteine. Annu Rev Nutr 2004;24:539-77.

11. Eberhardt RT, Forgione MA, Cap A, Leopold JA, Rudd MA, Trolliet $\mathrm{M}$, et al. Endothelial dysfunction in a murine model of mild hyperhomocysteinemia. J Clin Invest 2000;106:483-91.

12. Zhang $\mathrm{R}, \mathrm{Ma} J$, Xia $\mathrm{M}$, Zhu $\mathrm{H}$, Ling W. Mild hyperhomocysteinemia induced by feeding rats diets rich in methionine or deficient in folate promotes early atherosclerotic inflammatory processes. J Nutr 2004;134:825-30.

13. Afaf A, Sayed S. Lipid profile and levels of homocysteine and total antioxidant capacity in plasma of rats with experimental thyroid disorders. J Basic Appl Zool 2015;72:173-8.

14. Jacobsen DW. Hyperhomocysteinemia and oxidative stress: time for a reality check? Arterioscler Thromb Vascular Biol 2000;20:1182-4.

15. Landmesser U, Dikalov S, Price SR, McCann L, Fukai T, Holland $\mathrm{SM}$, et al. Oxidation of tetrahydrobiopterin leads to uncoupling of endothelial cell nitric oxide synthase in hypertension. J Clin Invest 2003;111:1201-9.

16. Cha JY, Repa J. The liver X receptor (LXR) and hepatic lipogenesis: the carbohydrate-response element-binding protein is a target gene of LXR. J Biol Chem 2007;282:743-51. 
17. Denechaud PD, Bossard P, Lobaccaro JM, Millatt L, Staels B, Girard J. ChREBP, but not LXRs, is required for the induction of glucose-regulated genes in mouse liver. J Clin Invest 2008;118:956-64.

18. Dentin R, Benhamed F, Hainault I, Fauveau V, Foufelle F, Dyck JR. Liver-specifi c Inhibition of ChREBP improves hepatic steatosis and insulin resistance in ob/ob mice. Diabetes 2006;55:2159-70.

19. Charrouf Z, Guillaume D. Ethnoeconomical, ethnomedical, and phytochemical study of Argania spinosa (L.) Skeels. J Ethnopharmacol 1999;67:7-14.

20. Necib Y, Bahi A, Zerizer S. Argan oil (Argania spinosa L) Provides protection against mercuric chloride induced oxidative stress in rat Albinos Wistar. Int J Basic Appl Sci 2013;2:73-80.

21. Cherki M, Berrougui H, Drissi A, Adlouni A, Khalil A. Argan oil: which benefits on cardiovascular diseases? Pharmacol Res 2006;54:1-5.

22. Bradford MA. Rapid and sensitive method for the quantities of microgram quantities of protein utilizing the principle of protein-dye binding. Anal Biochem 1976;72:248-54.

23. Weckbercker G, Cory JG. Ribonucleotide reductase activity and growth of glutathione-depended mouse leukaemia L 1210 cells in vitro. Cancer Lett 1988;40:257-64.

24. Aebi H. Catalase: methods for enzymatic analysis. Acadamic Press 1974;2:674- 84

25. Curro M, Gugliandolo A, Gangemi C, Risitano R, Ientile R, Caccamo D. Toxic effects of mildly elevated homocysteine concentrations in neuronal-like cells. Neurochem Res 2014;39:1485-95.

26. Faeh D, Chiolero A, Paccaud F. Homocysteine as a risk factor for cardiovascular disease: should we (still) worry about it? Swiss Med Wkly 2006;136:745-56.

27. Baszczuk A, Kopczynski Z. Hyperhomocysteinemia in patients with cardiovascular disease. Postepy Hig Med Dosw 2014;68:579.

28. Mudd SH. Hypermethioninemias of genetic and non-genetic origin: a review. J Med Genet C Semin Med Genet 2011;157:3-32.

29. Viggianoa A, Viggianoa E, Mondaa M, Ingrossob D, Pernac AF, Luca BD. Methionine-enriched diet decreases hippocampal antioxidant defences and impairs spontaneous behaviour and long-termpotentiation in rats. Brain Res 2012;1471:66-74.

30. Yamada H, Akahoshi N, Kamata S, Hagiya Y, Hishiki T, Nagahata $\mathrm{Y}$, et al. Methionine excess in diet induces acute lethal hepatitis in mice lacking cystathionine $\gamma$-lyase, an animal model of cystathioninuria. Free Radical Biol Med 2012;52:1716-26.

31. Kirac D, Negis Y, Ozer NK. Vitamin E attenuates homocysteine and cholesterol induced damage in rat aorta. Cardiovascular Pathol 2013;22:465-72.

32. Welch GN, Upchurch GR, Farivar RS, Pigazzi A, Vu K, Brecher P. Homocysteine-induced nitric oxide production in vascular smooth muscle cells by NF-kappaB dependent transcriptional activation of Nos2. Proc Assoc Am Physicians 1998;110:22-31.

33. Stipanuk MH, Dominy JE, Lee JI, Coloso RM. Mammalian cysteine metabolism: new insights into the regulation of cysteine metabolism. J Nutr 2006;136:1652S-59S.

34. Milton NGN. Homocysteine inhibits hydrogen peroxide breakdown by catalase. Open Enzyme Inhibition J 2008;1:34-41.

35. Góth L, Rass P, Pay A. Catalase enzyme mutations and their association with diseases. Mol Diagn 2004;8:141-9.

36. Ho YS, Xiong Y, Ma W, Spector A, Ho DS. Mice lacking catalase develop normally but show differential sensitivity to oxidant tissue injury. J Biol Chem 2004;279:32804-12.

37. Margoliash E, Novogrodsky A. A study of the inhibition of catalase by 3-amino-1:2:4:-triazole. Biochem J 1958;68:468-75.

38. Putnam CD, Arvai AS, Bourne Y, Tainer JA. Active and inhibited human catalase structures: ligand and NADPH binding and catalytic mechanism. J Mol Biol 2000;296:295-309.

39. Milton NGN. Amyloid- $ß$ binds catalase with high affinity and inhibits hydrogen peroxide breakdown. Biochem J 1999;344:293-6.
40. Benmebarek A, Zerizer S, Laggoune S, Kabouche Z. Effect of Stachys mialhesi de Noé on the inflammation induced by hyperhomocysteinemia in cardiovascular diseases. Scholar Res Library 2013;5:212-23.

41. Gallai V, Caso V, Paciaroni M, Cardaioli G, Arning E, Bottiglieri T, et al. Mild hyperhomocysteinemia: a possible risk factor for cervical artery dissection. Stroke 2001;32:714-8.

42. Papatheodorou L, Weiss N. Vascular oxidant stress and inflammation in hyperhomocysteinemia. Antioxid Redox Signal 2007:9:1941-58.

43. Lamda S, Aggoun C, Naimi D. The effects of homocysteine on plasma biochemical parameters and aortic matrix metalloproteinases activities. Innov Acad Sci 2014;7:975-491.

44. Pacher P, Beckman JS, Liaudet L. Nitric oxide and peroxynitrite in health and disease. Physiol Rev 2007;87:315-424.

45. Cooke JP, Dzau VJ. Nitric oxide synthase: role in the genesis of vascular disease. Annu Rev Med 1997;48:489-509.

46. Kanani PM, Sinkey CA, Browning RL, Allaman M, Knapp HR, Haynes WG. Role of oxidant stress in endothelial dysfunction produced by experimental hyperhomocysteinemia in humans. Circulation 1999;100:1161-8.

47. Rolland PH, Friggi A, Barlatier A. Hyperhomocysteinemiainduced vascular damage in the minipig. Captoprilhydrochlorothiazide combination prevents elastic alterations. Circulation 1995;91:1161-74.

48. Zulli A, Hare DL. High dietary methionine plus cholesterol stimulates early atherosclerosis and late fibrous cap development which is associated with a decrease in GRP78 positive plaque cells. Int J Exp Pathol 2009;90:311-20.

49. Raghuveer G, Sinkey CA, Chenard C, Stumbo P, Haynes WG. Effect of vitamin $\mathrm{E}$ on resistance vessel endothelial dysfunction induced by methionine. Am J Cardiol 2001;88:285-90.

50. Barbato JC, Catanescu O, Murray K, DiBello PM, Jacobsen DW. Targeting of metallothionein by L-homocysteine: a novel mechanism for disruption of zinc and redox homeostasis. Arterioscler Thromb Vasc Biol 2007;27:49-54.

51. Hamelet J, Demuth K, Dairou J, Ledru A, Paul JL, Dupret JM. Effects of catechin on homocysteine metabolism in hyperhomocysteinemic mice. Biochem Biophys Res Commun 2007;355:221-7.

52. Yalc S, Unlucerci Y, Giris M, Olgac V, Dogru-Abbasoglu S, Uysal M. Oxidative and nitrosative stress and apoptosis in the liver of rats fed on high methionine diet: protective effect of taurine. J Nutr 2009;25:436-44.

53. Meng MD, Weina MD, Ph D, Jingyu BS, Jijun BS, Jianquan MD Quercetin reduces serum homocysteine level in rats fed a methionine-enriched Diet. J Nutr 2013;29:661-6.

54. Masella R, Giovannini C, Vari R, Di Benedetto R, Coni E, Volpe R. Effect of dietary virgin olive oil phenols on low-density lipoprotein oxidation in hyperlipidemic patients. Lipids 2001;36:1195-202.

55. Ketterer B. Glutathione-S-transferase and prevention of cellular free radical damage. Free Radical Resear 1998;28:647-58.

56. Benajiba N, Morel S, De Leiris J, Boucher F, Charrouf Z, Mokhtar $\mathrm{N}$. The effect of argan oil on heart function during ischemia and reperfusion. Therapie 2002;57:246-52.

57. Zerizer S, Naimi D. Homocysteine: an independent risk factor in the atherogenic process. Egyptian Pharm J 2004;3:110-4.

58. Zerizer S, Zaher K, Boutaghane N, Laggoune S, Kabouche Z Comparative effect of Chrysanthemum Macrocarpum and Stachys Mialhesi on the rat's aorta exposed to homocysteine with B Vitamins. Scottish J Arts Soc Sciences Scientific Studies 2008;6:2047-1278

59. Kale MA, Bindu SM, Khadkikar P. Role of antioxidants and nutrition in oxidative stress: a review. Int J Appl Pharm 2015;7:975-7058.

60. kumar SV, Saritha G, Fareedullah Md. Role of antioxidants and oxidative stress in cardiovascular diseases. A Biol Res 2010;1:158-73.

61. Duffy SJ, Vita JA. Effects of phenolics on vascular endothelial function. Curr Opin Lipidol 2003;14:21-7. 